\title{
Angel investor's selection criteria: a comparative institutional perspective
}

Article

Accepted Version

Ding, Z., Sun, S. L. and Au, K. (2014) Angel investor's selection criteria: a comparative institutional perspective. Asia Pacific Journal of Management, 31 (3). pp. 705-731. ISSN 1572-9958 doi: https://doi.org/10.1007/s10490-014-9374-z Available at https://centaur.reading.ac.uk/70990/

It is advisable to refer to the publisher's version if you intend to cite from the work. See Guidance on citing.

To link to this article DOI: http://dx.doi.org/10.1007/s10490-014-9374-z

Publisher: Springer

All outputs in CentAUR are protected by Intellectual Property Rights law, including copyright law. Copyright and IPR is retained by the creators or other copyright holders. Terms and conditions for use of this material are defined in the End User Agreement.

\section{www.reading.ac.uk/centaur}

\section{CentAUR}

Central Archive at the University of Reading

Reading's research outputs online 


\section{Asia Pacific Journal of Management Angel Investor's Selection Criteria: A Comparative Institutional Perspective --Manuscript Draft--}

Manuscript Number:

Full Title:

Angel Investor's Selection Criteria: A Comparative Institutional Perspective

Article Type:

Manuscript

Keywords:

Institution-based view, angel investor, relationship-based institution, rule-based

institution

Corresponding Author:

Sunny Li Sun, PhD

University of Missouri - Kansas City

Garland, TX UNITED STATES

Corresponding Author Secondary

Information:

Corresponding Author's Institution:

University of Missouri - Kansas City

Corresponding Author's Secondary Institution:

First Author:

Zhujun Ding

First Author Secondary Information:

Order of Authors:

Zhujun Ding

Sunny Li Sun, PhD

Order of Authors Secondary Information:

Abstract:

Despite the important role of angel investors as critical financial providers for new ventures, little is known regarding how institutions make their investment decisions. While angels make decisions based on selection criteria during the first stage, they are also embedded within and affected by different institutional settings and as a result weight these criteria differently than other investors. We compare angel investors' selection criteria in China and Denmark using the comparative institutional perspective. We use a policy capturing approach and hierarchy linear modeling, revealing that since Chinese angels are embedded within relationship-based institutional settings they tend to reply more on strong ties such as family and friends in management team, as well as weighting risks less compared to Danish angels operating within more rule-based institutional contexts. 
ANGEL INVESTOR'S SELECTION CRITERIA:

A COMPARATIVE INSTITUTIONAL PERSPECTIVE

\author{
Zhujun DING \\ Department of Management \\ Chinese University of Hong Kong \\ No.12 Chak Cheung Street, Shatin, N.T., Hong Kong \\ zhujun@baf.msmail.cuhk.edu.hk
}

\author{
Sunny Li SUN* \\ Department of Global Entrepreneurship and Innovation \\ The Henry W. Bloch School of Management \\ University of Missouri - Kansas City \\ 5110 Cherry Street, Kansas City, MO 64110-2499 \\ Tel: (816)235-6070; Fax: (816)235-6529 \\ sunsli@umkc.edu
}

\footnotetext{
* Corresponding Author
} 
ANGEL INVESTOR'S SELECTION CRITERIA:

\title{
A COMPARATIVE INSTITUTIONAL PERSPECTIVE
}

\begin{abstract}
Despite the important role of angel investors as critical financial providers for new ventures, little is known regarding how institutions make their investment decisions. While angels make decisions based on selection criteria during the first stage, they are also embedded within and affected by different institutional settings and as a result weight these criteria differently than other investors. We compare angel investors' selection criteria in China and Denmark using the comparative institutional perspective. We use a policy capturing approach and hierarchy linear modeling, revealing that since Chinese angels are embedded within relationship-based institutional settings they tend to reply more on strong ties such as family and friends in management team, as well as weighting risks less compared to Danish angels operating within more rule-based institutional contexts.
\end{abstract}

Key Words: Institution-based view, angel investor, relationship-based institution, rule-based institution. 
The difficulty of obtaining adequate external capital has been recognized as a major constraint on the formation and growth of new business ventures (Cassar, 2004). Angel investors, as private investors who give risk capital to the ventures in the early stages, provide critical financial as well as managerial support (Landström, 1995; Maxwell, Jeffrey, \& Lévesque, 2011). For example, $5 \%$ of the population in the United States is business angels, collectively investing $\$ 108$ billion USD per year or 3.5 times the amount invested in start-ups by venture capital funds (Bygrave \& Reynolds, 2004). While scholars have begun to recognize that different institutional contexts could influence venture capitalists' (VCs) decision criteria (Bruton, Ahlstrom, \& Puky, 2009; Zacharakis, McMullen, \& Shepherd, 2007), we have little idea how institutions play a role in affecting angel investors' decisions to invest directly in small unquoted companies.

While formal venture capitalists could rely on sophisticated due diligence and term sheet tools to build a solid investment portfolio (Cumming, Schmidt, \& Walz, 2010), angel investors are more likely to depend on less formal procedures and personal relationships to select their projects and allocate investments (Duxbury, Haines, \& Riding, 1996; Sudek, 2006). This makes angels more embedded in the local institution than venture capitalists, some of whom are pursuing global deals (Gu \& Lu, 2010). Institutional contexts might therefore exert a higher impact on angel investor' decisions than them on venture capitalists' decision. This study 
therefore aims to understand how angle investors' decision-making differs in different institutional settings.

Economic history shows that institutions generate either productive or unproductive entrepreneurial activities (Baumol, 1996; North, 1990). Economic transactions are also affected by noneconomic factors such as social structure and network ties (Granovetter, 1985). Defined as "the rule of the game in a society" (North, 1990: 3), institutions serve as constraints that regulate economic activities, as well as instruct information distribution and the incentive structure (Bruton \& Ahlstrom, 2003; Zacharakis et al., 2007). In this study we differentiate between two dominant institutional arrangements, rule-based and relationship-based institution, that profoundly affect exchanges, transactions, and entrepreneurial activities including angel investments (Peng, 2003). Referring to Zacharakis et al. (2007)'s finding that VCs operating in rule-based institution weight more market factors than VCs operating in relationship-based institution, we developed our hypotheses and found that these institutional distinctions in different countries enable angel investors to have different attitudes toward new ventures' characteristics. We focus on three key selection criteria: the source of the business plan, risk, uncertainty, and relationship with the start-up team members. These correspond to the three underlining decision factors: discovery of opportunities, evaluation, and monitoring. A theoretical framework for the angel investment decision model under different institutional settings is provided in Figure 1. Guided by the comparative institutional perspective, we 
carefully compare the institutional arrangements in China and Denmark in order to find their distinctions and influences on angel investors' decisions.

\section{[Figure 1]}

We focus on angel investors' decisions at the selection stage. As the first stage in the investment decision process the selection stage has the highest rejection rate among all financing rounds that over $90 \%$ of the business proposals are rejected (Feeny, Haines, \& Riding, 1999; Riding, Madill, \& Haines, 2007). Angel investors from different institutions share similar criteria in their selections, while differing in the way they weight these criteria because the presence or absence of certain institutional arrangements may increase or reduce perceptions of risk, transaction costs, and opportunistic behaviors (Peng, Sun, Pinkham, \& Chen, 2009).

This study can make three significant theoretical contributions. First, to our best knowledge it is the first attempt to explore institutional differences in business angel decision criteria. Although previous studies conducted in varied countries have showed that angel investors in different countries have different behaviors, how the institutional system affects these difference has never been examined. A greater understanding of the rules of the game from a comparative institutional perspective will aid entrepreneurship researchers as well as would-be entrepreneurs, potential investors, and government policy makers attempting to revitalize their national economies. 
Second, we provide entrepreneurs with insights into angel investors' selection polices.

Although there are a large number of potential investors and large amount of money, the ability of start-up ventures to attract funding has been extremely limited (Ring, Duxbury, \& Haines, 1997). Understanding the investment decision process might help identify the critical reason that causes an opportunity to be rejected and increase the investment success rate.

Third, as many developing economies have undertaken fundamental transitions toward market-based economies since the 1980s, improved knowledge regarding individual behaviors and decision-making in these transition countries has become more important both for theory and practice. While the often-studied actors in transition economies are organizations (Peng, 2003), individual actors affected by the fundamental institutional changes are less well-studied. While relationship-based institution transmits to rule-based institution, our model could further help entrepreneurs understand the dynamics and evolution of angel investors' selection criteria.

\section{A COMPARATIVE INSTITUTIONAL PERSPECTIVE}

\section{Entrepreneur and Angel Investor under Rule-Based and Relationship-Based Institutions}

Institutional theory suggests that entrepreneurs and investors will adapt to opportunity discoveries, evaluation and exploitation activities, incentive structures, and enforcement mechanisms within their institutional environments (Baker, Gedajlovic, \& Lubatkin, 2005; Bruton \& Ahlstrom, 2003; Bruton, Ahlstrom, \& Puky, 2009; Bruton, Filatotchev, Chahine, \& 
Wright, 2010; North, 1990; Peng et al., 2009). The co-existence of two important institutional context types is widely recognized: rule-based and relationship-based institutions. Both have been found to have strong influences on venture capitalist's decision-making policies and procedures (Bruton et al., 2009; Peng, 2003; Zacharakis et al., 2007). Rule-based institutions, which exist in most developed economies, usually refer to a well-codified legal infrastructure, commercial law, corporate law, and contract law with sophisticated property right and investor protections that dominate the impersonal exchange regime. Relationship-based institutions, which exist in most developing economies, refers to a weak legal system with limited property right and investor protections that govern both relationship-based and personalized transactions (North, 1990). While most developing economies are struggling to make their transition from relationship-based to rule-based institutions (Bruton et al., 2009; Peng \& Zhou, 2005; Peng, 2003), the founding institution still constrains this transition and relationship-based institutions still largely dominate (Shinkle \& Kriauciunas, 2012).

Based on Scott (1995)'s classification, we map both entrepreneurs' and investors' responses in three dimensions: regulative, normative, and cognitive pillars, as shown in Table 1. In rule-based institutions the well-codified legal system and enforcing mechanisms reduce the transaction cost and uncertainty involved in building a cooperative, long-term, trusting exchange relationship, even with strangers. The well-specified investment contracts available in these institutions could protect investors' equity and interest, reduce the domain and severity 
of risk an investment is exposed to, and thereby encourage cooperation and trust between

entrepreneurs and angel investors (Poppo \& Zenger, 2002). Investors could apply weak ties in order to explore more heterogeneous information and investment opportunities (Peng \& Zhou, 2005; Ma, Huang, \& Shenkar, 2011).

[Table 1]

In contrast, in a weak legal system both entrepreneurs and angel investors face high transaction costs and uncertainty when developing a cooperative, long-term, trusting exchange relationship. They reduce these costs by cultivating intense and multiple ties or networks in order to create collective identities, avoid exchange hazards, and protect investment interests (Peng, 2001; Poppo \& Zenger, 2002; Webb, Tihanyi, Ireland, \& Sirmon, 2009). In this relationship-based institutional context entrepreneurs and investors usually rely on established strong ties in order to exploit opportunities (Peng \& Zhou, 2005; Ma et al., 2011).

\section{Angel Investor's Selection Criteria}

As the most important source of financial capital to entrepreneurial firms, angel investments have been increasingly studied since Wetzel's $(1981,1983)$ theoretical identification of its importance. The decision-making process is regarded as a key part of the angel investment procedure where investors judge the criteria of the new venture and make decisions (Feeney et al., 1999).

Research suggests that the informal investment decision process can be divided into two 
stages (Maxwell et al., 2011): 1) the selection stage where potential investors decide whether or not they are interested and will continue to consider the proposal, and 2) the post-selection stage where a more thorough assessment and potential negotiation will be conducted along with the final decision on whether or not to invest. We focus on the first stage where the investment criteria of the business proposal are evaluated and the rejection rate is the highest (Riding et al., 1997).

Investment criteria have been studied frequently in the prior literature and a wide variety of possible factors have been listed that angel investors consider when making investment decisions (Bachher \& Guild, 1996; Feeney et al., 1999; Haar, Starr, \& MacMillan, 1988; Haines, Madill, \& Riding, 2003; Landström, 1998; Sudek, 2006; Van Osnabrugge, 2000). Researchers investigating funding criteria note the importance of financial numbers and other easily verifiable factors such as sales, evidence of marketplace acceptance and size, as well as patent protection (e.g., Mason \& Stark, 2004). In addition to these rather objective factors, more subjective factors are also found including personality characteristics, work ethic, business understanding, and realistic notion of the venture's valuation (Feeney et al., 1999; Haines et al., 2003). However, previous research on criteria identification, evaluation, and aggregation are often conducted separately in different countries, including the US (Bygrave \& Reynolds, 2004), Canada (Duxbury et al., 1996), the United Kingdom (Short \& Riding, 1989), Sweden (Landström, 1995), Australia (Hindle \& Wenban, 1999), Asia (Tashiro, 1999; Hindle 
\& Lee, 2002), and so on. There are fewer attempts to understand how angel investors

differently emphasize these criteria in different countries where varied institutional contexts may have an impact.

\section{Comparison of China and Denmark}

In this study we compare Chinese and Danish angel investors' decision-making policies in order to identify the institutional influence while China and Denmark present as relationship-based and rule-based institutions respectively for these reasons. 1) Both counties have adapted civil law systems; however, the law system China adapted is influenced by the Soviet schema where the legislature retains the power to interpret statutes and the constitution remains ambiguous regarding judicial review of legislation. Law enforcement is very weak while corruption is notoriously rampant in practice (ranked number 76 in the corruption perception index, see Table 2a). China's investor protection systems, corporate governance, and accounting standards are significantly less developed than those of most countries according to the World Bank Governance Index (La Porta, Lopes-de-Silanes, Shleifer, \& Vishny, 1997, 1998; Allen, Qian, \& Qian, 2005). Chinese society clearly demonstrates the attributes of relationship-based institutions (Zhou \& Poppo, 2010). In contrast, Denmark has a long tradition of government openness, civic activism, and social trust with strong transparency and accountability mechanisms, ranking number 2 in the corruption perception 
index. In Denmark intellectual property rights are well-protected and contracts are

well-enforced, showing the attributes of a rule-based institution. 2) The freedom of market competition and government's enforcement of such a system vary significantly between China and Denmark. The heritage foundation's Economic Freedom Index describes the degree of private economic freedom mixed with a degree of government market regulation. While China is ranked number 138 in the 2012 Index, Denmark is ranked number 11 (see Table 2a). 3) The ease of starting up a business and investing in it is also different in China and Denmark.

According to the World Bank Doing Business Report 2011 (see Table 2b), Denmark maintains its creditable 6th position on overall "Ease of Doing Business," the highest-ranking country in the Europe. Meanwhile, China was ranked 79 out of 183 economies. Concerning investor protections Denmark was ranked 28 and China was ranked 98. These prominent differences between China and Denmark will accordingly provide us a good opportunity to differentiate between the effects of relationship- and rule-based institutions.

[Table $2 \mathrm{a}$ and $2 \mathrm{~b}]$

\section{HYPOTHESES DEVELOPMENT}

Under the institution comparative perspective we emphasize three criteria in investment opportunity discovery, evaluation, involvement, and monitoring.

\section{Discovering the Investment Opportunity}


Prior research found that familiarity with the business field, personal knowledge of the entrepreneur, and a high regard for the third party who brought the investment proposal to the investors for review were highly related to the investment decision (Harrison, Dibben, \& Mason, 1997). Usually third-party references can safeguard the exchange by reducing transaction costs and avoiding moral hazards (Williamson, 1979). A reference with a high reputation can give the investor confidence in the proposal's quality and entrepreneurial personality (Bian, 1997). In rule-based institutions individuals are embedded within an environment with a well-established legal system, higher social trust, and reliable government and market machinery; these are the root of trust in information from unfamiliar parties. Angel investors in this institutional context can therefore discover potential investment projects via weak tie referent parties. Untrustworthy behavior could be punished by social sanctions, helping induce cooperation (Hagen \& Choe, 1998). Although weak ties lack the effective content of infrequent interaction, they have advantages in carrying novel information and facilitating investment opportunities by providing nonredundant information embedded within separated network (Granovetter, 1973; Ma et al., 2011).

However, in a relationship-based institution most important exchanges are made through existing strong ties built via frequent interactions and reciprocal favors (Granovetter, 1973; Peng \& Zhou, 2005; Ma et al., 2011). These strong ties always control critical information that is not shared with others who do not have these ties or trust (Bian, 1997). The frequent 
interactions and reciprocal favors combined with risk-taking and successful fulfillment of

previous exchanges strengthen the motivation of individuals to rely on close relationships and invest acquired resources into the next exchange with a known partner (Peng \& Zhou, 2005). In a relationship-based institution such as China angel investors accordingly count on the reliability and dependability of previous interactions with the referent party in order to screen proposals over the credibility of strangers. Since angel investors tend to make a less thorough evaluation of potential investments but quicker investment decisions than venture capitalists (Mason \& Harrison, 1996), if a strong tie such as a close friend brings the opportunity a Chinese angel investor weight it more heavily than a Danish investor.

H1: Chinese angel investors more strongly emphasize an opportunity brought by a friend compared to a cold call in selecting investment opportunities than Danish investors do.

\section{Evaluating the Investment Opportunity}

Unlike venture capitalists who have a portfolio of investments to balance successful and failed investments (Cumming, 2006), angel investors tend more to carefully evaluate the rates of return and will have a systematically superior investment performance than VCs (Mason \& Harrison, 2002; Riding, 2008). At the macro level China's dynamic economy with its low starting point and high speed could provide more business opportunities than Denmark's more developed economy with slow development (see the comparison in Table $2 a$ ). In addition, China's low income level and standard of living could drive Chinese investors who seek large returns more strongly than Danish investors. Based on our comparative institutional 
perspective, we also argue that the transactions costs in a relationship-based institutional setting are higher than those in rule-based institutions. For example, China lacks the high level of legal enforceability that facilitates the application of contracts safeguarding market exchanges characterized by non-trivial hazards. Accordingly, Chinese investors rely on "relational reliability" (e.g., the trust in strong ties) to protect transactions associated with specialized assets and behavioral uncertainty (Zhou \& Poppo, 2010). In contrast, Danish investors could emphasize returns less strongly against the low level of transaction costs in a rule-based context.

At the micro level we must note the "sunk costs" of strong ties in relationship-based institutions (Northcraft \& Wolf, 1984). Strong ties take time and effort to build, and have high costs that cannot be recovered (Peng \& Zhou, 2005). The scale and scope of strong ties are often constrained with limited size. When either entrepreneurs or investors want to expand the scale or scope of a transaction the cost of strong ties will be multiplied in an extended network (Peng, 2003). However, based on the weak ties connecting opportunities Danish investors may be less concerned with sunk transaction costs. Considering the costs incurred prior to the particular investment opportunity we suggest:

H2a: Chinese angel investors more strongly emphasize returns in selecting investment opportunities than Danish angel investors do.

For angel investors risk could better be defined in terms of the amount potentially lost than in terms of variance in the outcome distribution because most do not allocate investments into a 
managed portfolio the way venture capitalists do (March \& Shapira, 1987). The rapid political, economic, and social changes occurring in a harsh transition economy such as China could increase start-ups' discontinuation rates at the high level of $10.28 \%$ in 2007 and $5.3 \%$ in 2011 , compared with a stable economy such as Denmark at 1.55\% in 2007 and 2.3\% in 2011 (Global Entrepreneurship Monitor (GEM), 2007, 2011). At the macro level, by operating within a highly dynamic and hostile environment with weak investor protections Chinese angel investors could expect to lose significantly more in some projects, and accordingly bear greater risks than Danish investors operating within a mature economy with strong minority investor right protections.

At the micro level, in a relationship-based institution both entrepreneurs and investors in China could frequently protect trust among strong ties by building relational reliability in order to reduce the liability under a weak legal environment (Zhou \& Poppo, 2010). They could respond to business failures by bestowing even greater trust or investments, namely called “throwing good money after bad" (Guler, 2007). A lengthy and inefficient bankruptcy environment could multiply this ironic effect of trust (Lee, Peng, \& Barney, 2007). In contrast, a Danish investor who relies more on weak ties in opportunity evaluation is less likely to fall into such potentially self-defeating trap and is more to explore alternative options (Shapiro, 1987).

However, strong ties also carry the advantage of the "cushion" effect. In-group members 
such as family always step in to help out group members who confront a large and possibly

catastrophic loss after choosing a risky option in a relationship-based context such as China

(Weber \& Hsee, 1998). A Chinese investor could therefore tolerate a greater investment loss

than a Danish investor because the Chinese investor has built-in backup. Thus, we have:

$H 2 b$ : Chinese angel investors less emphasis on risk in selecting investment opportunities than Danish angel investors do.

\section{Involvement and Monitoring}

In addition to their financial role in new venture development, angel investors also play a

substantial role in the strategy-making and daily operations of these ventures (Wiltbank, Read,

Dew, \& Sarasvathy, 2009). An angel investor could gain ex post control and exert power over the investment in a high-risk small-firm environment via active involvement after investment (Van Osnabrugge, 2000). Under the comparative institutional perspective, in a relationship-based institution where intellectual property rights are less protected and there is a friend or family member on the start-up team angel investors can more easily become accepted by the team and become involved in the business with entrepreneurs' cooperation. However, in rule-based institutions even without these bridging ties an entrepreneur team can build trust relationships with an angel investor because people in latter institution believe that most people can be trust (Ma et al., 2011).

Monitoring ventures following investment is another consideration for angel investors. In a relationship-based institution the monitoring roles of the board of directors and minority 
shareholders are weak. Angel investors have tremendous difficulties protecting their interests through formal channels such as board or shareholder meetings; instead they rely on strong ties with the funded firm, government, or judicial system to further aid in the monitoring process and legal issues (Howson \& Clarke, 2011). It is not uncommon that a Chinese investor cannot access the funded firm's accounting report (Ahlstrom, Bruton, \&Yeh, 2007). A strong connection such as a family member or friend on the entrepreneurial team can therefore serve as a springboard for monitoring assistance since the family or friend would pay the penalty of losing trust (or "face") if he or she violated the investor's rights or did not disclosure critical insider information to the investor (Peng \& Zhou, 2005). In contrast, in a rule-based institution the entrepreneurial team maintains their fiduciary duties to investors even without personal connections. The strong protection of minority investor rights and corporate governance also allows angel investor to formulate an optimal contract with contingency incentive plans in order to overcome any moral hazard or adverse selection issues (Van Osnabrugge, 2000). A Danish investor can therefore trust stranger when investing. We suggest that: H3a: Chinese angel investors more strongly emphasize the venture's entrepreneurial team when it includes a friend as a member than Danish angel investors do.

H3b: Chinese angel investors more strongly emphasize the venture's entrepreneurial team when it includes a family member than Danish angel investors do. 
Angel investment decisions have been studied using different methodologies including questionnaires, verbal protocols, interviews, etc. (Duxbury et al., 1996; Maxwell et al., 2011; Prowse, 1998). We used the policy capturing approach from the social judgment theory (Slovic \& Lichtenstein, 1971) in order to uncover how these assessment factors or criteria are used in human decision-making (e.g., Hitt, Ahlstrom, Dacin, Levitas, \& Svobodina, 2004; Hitt, Dacin, Levitas, Arregle, \& Borza, 2000; Lovallo, Clarke, \& Camerer, 2012; Zacharakis et al., 2007). Differing from surveys and interviews in prior studies, this method avoids relying on investors' often biased retrospections and instead allows researchers to observe directly entrepreneurial decisions (Davidson, 2007; Lovallo et al., 2012). We adapted this method for angel investment decision; it has not been used in this domain so far as we know.

\section{Sample}

MBA students from two large universities in China $(\mathrm{N}=60)$ and Denmark $(\mathrm{N}=53)$ who finished courses related to either entrepreneurship or venture financing took part in this programs. As stated in their career statements and curriculum vista available in MBA resume booklets they had prepared and evaluated business plans, and some were in the process of conceiving entrepreneurships or investing in private companies. The two groups are not significantly different in demographics such as gender $(\gamma=-.057, \mathrm{p}=.682)$ and age $(\gamma=-.209$, 
$\mathrm{p}=.130$ ). The respondents read the instructions asking them to play the role of angel investors and examine a summary prepared by the assistant. Each respondent examined eight investment scenarios and indicated their interest in looking further into the projects. Respondents varied in their investment scenarios as described above.

\section{Variables}

Following Hitt et al. (2000, 2004), we collected the criteria for angel investments from the literature (as discussed above), itemized them, and scanned the final list with local angel investors. The detailed description can be found in Table 3. The eight investment criteria in each scenario act as independent variables and control variables at level-1 (the scenario level). They cover a broad range of new venture characteristics including source of the business plan, investment return, risk of failure, relationship with members of the start-up team, compatibility with investors' expertise and interests, start-up team capabilities, opportunity to become involved in the new venture, and exit plan (Feeney et al., 1999; Landström, 1995; Mason \& Stark, 2004; Maxwell et al., 2011). We provided a brief description of each criterion in the front page of the questionnaire in order to help respondents' understanding.

We then constructed investment project scenarios by randomly assigning (using a random number generator) the levels of the investment criteria in each case in order to avoid multicollinearity. We examined the correlations of the independent variables in order to ensure 
the randomization. We also ensured that the variance of each variable was balanced in the construction of the scenarios so that each variable had a relatively equal probability of having an effect on the dependent variable.

Dependent variable. The selection tendency to invest is the dependent variable of the study. It was measured by the average of two items, "Is this company attractive for you to invest?" with a five-Likert scale from $1=$ very unattractive to $5=$ very attractive, and "What is the probability that you would invest in this start-up business?" with a five-Likert scale from $1=$ low probability to $5=$ high probability. Individuals' answers to these two questions were highly correlated $(\gamma=.868, p<.000)$. The two groups, Chinese and Danes, were not significantly different in selection tendency $(t$-value $=.983, p=.326)$.

Independent variables. For the source of business plan, we use the dummy for 1 (friend) and 0 (cold call ) as our independent variables. Using dummies for comparing different categories is often adapted in research using policy capturing method (Boatsman \& Robertson, 1974; York, 1989). For the investment return, we use three scale from 1(low return) to 3 (high return). For risk of failure, we use three scale from 1 (possibly huge loss) to 3 (possibly little loss). For relationship with members of the start-up team, we use two dummies: friend (1) and stranger (0), and family (1) and stranger (0).

\section{[Table 3]}

Control Variable. At level-1, all the other scenario characteristics act as the control 
variables (as show in Table 3). At level-2 (the individual level) we controlled the basic demographic variables including age, gender, and income (Maula, Autio, \& Arenius, 2005;

Szerb, Rappai, Makra, \& Terjesen, 2007). We also controlled the individual experiences relating to informal investment: previous informal investment was measured using the question "Whether you have being an angel investor before?"; previous finance investment was measured using the question "Do you have experience in financial investment, such as stocks, real estates, foreign exchange, bonds?"; entrepreneurial experience was measured using the question “Do you have startup experience?” (Maula et al., 2005; Wiltbank et al., 2009).

\section{RESULTS}

\section{China and Denmark Comparison}

We used a multilevel model in our study where investment criteria and investors' decisions were at level-1 and individual characteristics were at level-2. Since each individual reviewed eight scenarios, there are 480 observations for Chinese sample and 424 observations for Danish sample. For the scenarios embedded in each respondent we used Hierarchical Linear Modeling (HLM) to analyze the data (Bryk \& Raudenbush, 1992; Hitt et al., 2000, 2004), control within-respondent variance (i.e., eight cases per respondent), and assesses between-respondent variance (i.e., between respondents within each country) and group effects with coefficients that can be interpreted similar to an ordinary least squares (OLS) regression analysis (Bryk \& 
Raudenbush, 1992). All explanatory variables were centered on their grand mean when entered into the model. The descriptive statistics and correlations for the level-1 and level-2 variables are shown in Table 4.

[Table 4]

We first developed separate models for the Chinese and Danish samples using hierarchical linear modeling (HLM). From the separate results for China and Denmark, we can see that all eight criteria in level-1 have very significant effects on investment propensity for Chinese investors. For Danish investors, the relationship with the entrepreneurial team does not significantly influence the selection tendency toward investment. This may reveal that Danish investors are less influenced by a relationship-based institutional context as Chinese investors.

We build Models 3 to 5 in Table 5 to analyze the data including both the China and Denmark sample, adding the country dummy. In Model 3 we set the criteria at level-1 and find substantial between-individual differences that have significant coefficients for all eight scenarios. In Model 2 we add the level-2 control variables, and in Model 3 we add the country moderation and perceived financial institution into the model. Hypothesis 1 indicates that Chinese investors favor a business plan received from a friend compared to cold call more than Danish investors. However, results fail to find significant difference for Chinese and Danish investors $(\gamma=.175, p=.119)$, although the coefficient is positive. For the return criterion, the results does not fully support $\mathrm{H} 2 \mathrm{a}$ that Chinese investors more heavily emphasize this criterion 
than Danish investors $(\gamma=.024, p=0.755)$, however, the coefficient is positive. For hypothesis 2b, results in Model 6 suggest that Chinese investors less emphasis on risk in selecting investment opportunities than Danish angel do $(\gamma=-.234, p<.05) . \mathrm{H} 2 \mathrm{~b}$ therefore receives support. Finally, for the relationship between the entrepreneurial team and investors (H3ab), Chinese investors more heavily emphasize family $(\gamma=.233, p<0.1)$ and friends $(\gamma=.368, p<$ 0.05) over strangers than Danish investors. Both $\mathrm{H} 3 \mathrm{a}$ and $\mathrm{H} 3 \mathrm{~b}$ accordingly receive supports.

Following Hitt et al.(2000, 2004), we also have a robustness check through comparing the weight each criterion received from Chinese and Danish investors respectively. We test hypotheses through separating models for China (Model 4) and Denmark (Model 5). The coefficients obtained in these separate samples are compared using a $z$-test, the technique summarized by Cohen and Chohen (1983: 111) and commonly applied in criterion comparisons (Hitt et al. 2000, 2004). The results confirmed that Chinese investors put less weight in risk $(z=-1.62, p<0.05)$, while put more weight on the relationship with team members, who are friend $(z=1.64, p<0.05)$ and family $(z=2.85, p<0.01)$ compare to stranger. Z-score on Source-friend between Chinese and Danish investor is high, but not reach significant level. Therefore, $z$-test confirms that $\mathrm{H} 2 \mathrm{~b}, \mathrm{H} 3 \mathrm{a}$, and $\mathrm{H} 3 \mathrm{c}$ get strong supports, but $\mathrm{H} 1$ and H1a not.

\section{[Table 5]}




\section{DISCUSSION}

Under a comparative institutional perspective we examined how institutional context

influences angel investors' business project selection. One important finding is that institutions have significant impact on angel investor decision-making. Compared to Danish investors,

Chinese angel investors would weight their relationships with start-up teams higher than

Danish investors that they tend to invest in new ventures that have family members or friends

on the entrepreneurial team, while Danish investors give more equal treatment to family

members, friends, and strangers. These findings are supported by previous survey in GEM,

although GEM has not identified the significance of differences. The aggregated GEM 2007

adult population survey at the national level found that only $4.6 \%$ of Chinese angel investors

would invest in a stranger, while $42 \%$ would invest in family and $47.6 \%$ would invest in a

friend. Meanwhile, in Denmark, $17.1 \%$ would invest in a stranger, $36.3 \%$ in family, and $27.4 \%$

in a friend. Our results also shows that both Chinese and Danish investors tend to invest in

opportunity with lower risk, while Chinese investors tend to weigh the risk less. These findings

highlight the importance of the selection criteria differences between China and Denmark.

However, do all these differences arise from the variances between relationship-based

institution and rule-based institutions?

A challenging explanation comes from the culture dimension. Although the GLOBE culture survey has not identified the significant difference between China and Denmark (see 
Table 2a for details), Hofstede's (1991) culture dimension reveals that Chinese and Danish investors are sharply different in the Individualism-Collectivism dimension. The score for China was 20 (high collectivism) and for Denmark 74 (low collectivism) in the survey taken nearly 40 years ago. However, some scholars have recently argued that China values a strong inner self under Confucian traditional culture and could represent a more radical individualism than the Western one (Herrmann-Pillath, 2010). Others argue that a collectivism culture could move to individualism as a consequence of economic growth and modernization (Hamamura, 2012). In addition, our result on $\mathrm{H} 1$ indicates that Chinese angle investors not more heavily rely on strong ties to seek investment opportunities than Denmark investors. Chinese investors may explore widely to discover qualified business plan. We therefore do not adopt this alternative perspective, although previous research shows that collectivism could partially explain the importance of strong ties in opportunity recognition within relationship-based institutions (Ma et al., 2011).

This study makes contributions to the literature from several aspects. First, for theoretical contribution, we develop a theoretical comparative institutional perspective explaining why angel investors have different selection criteria under different institutional environments. We underscore the importance of whether the institutional context is relationship-based or rule-based in order to better understand entrepreneurial activities; "[t]ransactions of all kinds" at all levels of the firm or individual "are rife with . . . social connections" that have different 
institution support (Granovetter, 1985: 495-499). These different connections or ties could facilitate different trust levels via norms of reciprocity and successful cooperation in networks. They accordingly play a crucial and underappreciated role in fostering investments and entrepreneurial prosperity (Fukuyama, 1995).

Second, we enrich the research on angel investors' investment decision-making polices. Our findings may help reconcile the discovery of previous research conducted in different countries that angel investors' behavior is slightly different in different countries and institutional contexts. This study suggests that findings from numerous single-country studies must be qualified with an explicit comparisons and discussion concerning the enabling and constraining forces of the institutional framework. We also show that national institutions can be conceptualized in a way that captures the critical variations across countries that then can be used to explain individual behavior under different contexts.

Third, for methodology contribution, the use of policy capturing and HLM model enable us to empirically uncover the investor's emphasis on information while making informal investment decisions. Different from prior research conducted in a single-country setting, we examine at a larger picture and contrast China and Denmark as two distinct institutional settings. We conduct a between-countries comparison in order to explore the institutional contexts of informal investment. Perhaps the strongest message of our study is that given the same decision-making criteria, we must consider the context the individual investors are 
embedded within. At the individual level the political and market pressures faced by angel

investors might also be faced by other economic actors such as top executives and

entrepreneurs. The individuals making decisions are accordingly influenced by existing

institutional realities. HLM model can help us to identify these influences at different levels.

Lastly, for practical contribution, our findings can help policymakers promote a good

entrepreneurship policy. We reveal the shortfalls of relationship-based institution in

constraining the scale and scope of these ties. The weak legal protections and contract

enforcement could make entrepreneurs and investors over-embedded in strong tie relationships,

especially in start-up team. Policymakers might propose measures that help transform

rule-based institution in extending the scale and scope of angel investors' support. Moreover,

our finding can help entrepreneurs understand investors' selection criteria. According to many

studies of private investment the rejection rates for investment proposals are high (Mason \&

Harrison, 1995). High rejection rates prompt the need to better understand both the processes

and criteria that angel investors use to make their decisions. This study seeks to add the

explanations to investors' selection criteria.

\section{Limitations and Future Research}

This study has some limitations that clearly encourage further research. First, we have not directly measured either the tie strength or intensity in the relationship between entrepreneurs and investors in our policy capturing approach. Future research should examine the role of 
strong versus weak ties in angel investors' decision-making policies along with the

contribution of these ties to new venture performance. Collectively, such research can offer a detailed account of social relationships' effects on new venture investments.

Second, this study is the first to show the different investor selection criteria between

China and Denmark. However, do the differences between relationship-based and rule-based institutions sufficiently explain this variance? Future research may include additional emerging economies such as Asian and Latin American countries as well as developed economies in the sample. After controlling for additional cultural variances, a replication of this study with other countries could address any generalizability concerns stemming from using a sample surveying only two countries.

Third, we have not identified the selection criteria applied by angel investors that are different from those of formal venture capitalists. The literature already shows different investment criteria between angel investors and venture capitalists (Feeney et al., 1999; Van Osnabrugge, 2000; Shepherd, Zacharakis, \& Baron, 2003). However, little research has weighted these institutional influences on the different criteria applied by these two kinds of important investors. This study highlights the importance of a comparative institutional perspective on angel investor selection criteria, but remains to be done in order to fully understand the complexities of investors' decision-making in new ventures. 
Ahlstrom, D., Bruton, G., \& Yeh, K. 2007. Venture capital in China: Past, present, and future. Asia Pacific Journal of Management, 24: 247-268.

Allen, F., Qian, J., \& Qian, M. 2005. Law, finance, and economic growth in China. Journal of Financial Economics, 77: 57-116.

Bachher, J. S., \& Guild, P. D. 1996. Financing Early Stage Technology Based Companies: Investment Criteria Used by Investors. Frontiers of Entrepreneurship Research: 363-376.

Baker, T., Gedajlovic, E., \& Lubatkin, M., 2005. A framework for comparing entrepreneurship processes across nations. Journal of International Business Studies, 36: 492-504.

Baumol, W. J. 1996. Entrepreneurship: Productive, unproductive, and destructive. Journal of Business Venturing, 11: 3-22.

Bian, Y., 1997. Bringing strong ties back in: Indirect connection, bridges, and job search in China. American Sociological Review, 62: 355-385.

Boatsman, J., \& Robertson, J. 1974. Policy capturing on selected materiality judgments. Accounting Review, 49: 342-352.

Bruton, G. D., \& Ahlstrom, D. 2003. An institutional view of China's venture capital industry: Explaining the differences between China and the West. Journal of Business Venturing, 18(2): 233-259.

Bruton, G. D., Ahlstrom, D., \& Puky, T., 2009. Institutional differences and the development of entrepreneurial ventures: A comparison of the venture capital industries in Latin America and Asia. Journal of International Business Studies, 40: 762-778.

Bruton, G. D., Filatotchev, I., Chahine, S., \& Wright, M. 2010. Governance, ownership structure, and performance of IPO firms: The impact of different types of private equity investors and institutional environments. Strategic Management Journal, 31(5): 491-509.

Bryk, A. S., \& Raudenbush, S. W. 1992. Hierarchical linear models: Applications and data analysis methods. Thousand Oaks, CA: Sage.

Bygrave, W. D., \& Reynolds, P. D. 2004. Who finances startups in the USA? A comprehensive study of informal investors, 1998-2003. Frontiers of Entrepreneurship Research: Babson Park, MA: Babson College.

Carney, M., Gedajlovic, E., \&Yang, X., 2009. Varieties of Asian capitalism: Toward an institutional theory of Asian enterprise. Asia Pacific Journal of Management, 26: 361-380.

Cassar, G. 2004. The financing of business start-ups. Journal of Business Venturing, 19: 261-283.

Cohen, J., \& Cohen, P. 1983. Applied Multiple Regression/Correlation Analysis for the Behavioral Sciences. Hillsdale, NJ: Lawrence Erlbaum Associates.

Cumming, D. J. 2006. The Determinants of Venture Capital Portfolio Size: Empirical Evidence. Journal of Business, 79(3): 1083-1126.

Cumming, D., Schmidt, D., \& Walz, U. 2010. Legality and venture capital governance around the world. Journal of Business Venturing, 25: 54-72.

Davidsson, P. 2007. Method challenges and opportunities in the psychological study of entrepreneurship. In J. R. Baum, M. Frese, \& R. Baron (Eds.), The Psychology of Entrepreneurship, 287-323. Mahwah, NJ: Lawrence Erlbaum Associates.

Djankov, S., Qian, Y., Roland, G., \& Zhuravskaya, E. 2006. Who are China's entrepreneurs? American Economic Review, 96; 348-352. 
Duxbury, L., Haines, G. H, \& Riding, A. L. 1996. A personality profile of Canadian informal investors. Journal of Small Business Management, 34: 44-55.

Feeney, L., Haines, G. H., \& Riding, A. L. 1999. Private investors' investment criteria: Insights from qualitative data. Venture Capital, 1: 121-145.

Fukuyama F. 1995. Trust: The Social Virtues and the Creation of Prosperity. New York: Free Press.

Granovetter, M. S. 1985. Economic action and social structure: The problem of embeddedness. American Journal of Sociology, 91: 481-510.

Granovetter, M. S. 1973. The strength of weak ties. American Journal of Sociology, 78: 1360-1380.

Gu, Q., \& Lu, J.W. 2010. Effects of inward investment on outward investment: The venture capital industry worldwide 1985-2007. Journal of International Business Studies, 42: 263-284.

Guler, I. 2007. Throwing good money after bad? Political and institutional influences on sequential decision making in the venture capital industry. Administrative Science Quarterly, 52: 248-285.

Haar, N. E., Starr, J., \& MacMillan, C. 1988. Informal risk capital investors: Investment patterns on the East Coast of the U.S.A. Journal of Business Venturing, 3(1): 11-29.

Hagen, J. M., \& Choe, S., 1998. Trust in Japanese Interfirm relations: Institutional sanctions matter. Academy of Management Review, 23: 589-600.

Haines, G. H. Jr., Madill, J. J., \& Riding, A. R. 2003. Informal Investment in Canada: Financing Small Business Growth. Journal of Small Business and Entrepreneurship, 16(3-4): 13-40.

Hamamura T., 2012. Are cultures becoming individualistic? A cross-temporal comparison of individualism-collectivism in the United States and Japan. Personality and Social Psychology Review, 16, 3-24.

Harrison, R. T., Dibben, M. R., \& Mason, C. M. 1997. The role of trust in the informal investor' s investment decision. Entrepreneurship: Theory and Practice, 21(4): 63-81.

Herrmann-Pillath C., 2010. Social capital, Chinese style: individualism, relational collectivism and the cultural embeddedness of the institutions-performance link. China Economic Journal, 2, 325-350.

Hindle, K. G, \& Lee, L. 2002. An exploratory investigation of informal venture capitalists in Singapore. Venture Capital, 4(2): 169-181.

Hindle, K. G., \& Wenban, R. 1999. Australia's informal venture capitalists: an exploratory profile. Venture Capital, 1: 169-86.

Hitt, M. A., Ahlstrom, D., Dacin, M. T., Levitas, E., \& Svobodina, L., 2004. The institutional effects on strategic alliance partner selection in transition economies: China vs. Russia. Organization Science, 15: $173-185$.

Hitt, M. A., Dacin, M. T., Levitas, E., Arregle, J.-L., \& Borza, A., 2000. Partner selection in emerging and developed market contexts: Resource-based and organizational learning perspectives. Academy of Management Journal, 43, 449-467.

Hofstede, G. 1991. Cultures and Organizations: Software of the Mind. London, UK: McGraw-Hill.

Howson, N. C., \& Clarke, D. C. 2011. Pathway to minority shareholder protection: Derivative actions in the People's Republic of China. SSRN eLibrary http://ssrncom/paper=1968732.

La Porta, R., Lopez-de-Silanes, F., Shleifer, A., \& Vishny, R. W. 1997.Trust in large organizations. American Economic Review, 87(2): 333-338.

La Porta, R., Lopez-de-Silanes, F., Shleifer, A., \& Vishny, R. W. 1998. Law and finance. Journal of Political Economy, 106: 1113-1155.

Landström, H. 1998. Informal investors as entrepreneurs. Technovation, 18(5): 1998.

Landström, H. 1995. A Pilot Study on the Investment Decision-Making Behavior of Informal Investors 
in Sweden. Journal of Small Business Management, 33 (3): 67-76.

Lee, S. H., Peng, M. W., \& Barney, J. B., 2007. Bankruptcy law and entrepreneurship development: A real options perspective. Academy of Management Review, 32: 257-272.

Lovallo, D., Clarke, C., \& Camerer, C., 2012. Robust analogizing and the outside view: Two empirical tests of case-based decision making. Strategic Management Journal, 33, 496-512.

Ma, R., Huang, Y.-C., \& Shenkar, O. 2011. Social networks and opportunity recognition: A cultural comparison between Taiwan and the United States. Strategic Management Journal, 32, 1183-1205.

March, J. G., \& Shapira, Z. 1987. Managerial perspectives on risk and risk taking. Management Science, 33: 1404-1418.

Mason, C. M., \& Harrison, R. T. 2002. Is it worth it? The rates of return from informal venture capital investments. Journal of Business Venturing, 17: 211-236.

Mason, C. M., \& Harrison, R. T. 1996. Why 'business angels' say no: A case study of opportunities rejected by an informal investor syndicate. International Small Business Journal, 14, 35-51.

Mason, C. M., \& Stark, M. 2004. What do Investors Look for in a Business Plan? International Small Business Journal, 22(3): 227-248.

Maula, M., Autio, E., \& Arenius, P. 2005. What drives micro-angel investments? A large sample study of factors explaining micro-angel investments. Small Business Economics, 25(5): 459-475.

Maxwell, A.L., Jeffrey, S.A., \& Lévesque, M. 2011. Business angel early stage decision making. Journal of Business Venturing, 26: 212-225.

McMillan, J., \& Woodruff, C., 2002. The central role of entrepreneurs in transition economies. Journal of Economic Perspectives, 16: 153-170.

North, D.C. 1990. Institutions, Institutional Change, and Economic Performance. New York: Cambridge University Press.

North D.C., Wallis J.J., \& Weingast B.R., 2009. Violence and Social Orders: A Conceptual Framework for Interpreting Recorded Human History. Cambridge, UK: Cambridge University Press,

Northcraft, G. B., \& Wolf, G. 1984. Dollars, sense, and sunk costs: A life cycle model of resource allocation decisions. Academy of Management Review, 9: 225-234.

Peng, M. W. 2001. How entrepreneurs create wealth in transition economies. Academy of Management Executive, 15: 95-108.

Peng, M. W. 2003. Institutional transitions and strategic choices. Academy of Management Review, 28 : 275-296.

Peng, M. W., Sun, S. L., Pinkham, B., \& Chen, H. 2009. The institution-based view as a third leg for a strategy tripod. Academy of Management Perspectives, 23: 63-81.

Peng, M. W, \& Zhou, J. 2005. How network strategies and institutional transitions evolve in Asia. Asia Pacific Journal of Management, 22: 321-336.

Poppo, L., \& Zenger, T. 2002. Do formal contracts and relational governance function as substitutes or complements? Strategic Management Journal, 23: 707-725.

Prowse, S. 1998. Angel investors and the market for angel investments. Journal of Banking \& Finance, 22: 785-192.

Riding, A. L. 2008. Business angels and love money investors: segments of the informal market for risk capital. Venture Capital, 10(4): 355-369.

Riding, A. L., Duxbury, L., \& Haines, G. 1997. Financing enterprise development: decision-making by Canadian angels. Conference Proceedings for Entrepreneurship Division of the Association of 
Management and International Association of Management, 17-22, August.

Riding, A. L., Madill, J. J., \& Haines, G. H. 2007. Investment decision making by business angels. In H. Landstrom (Ed.), Handbook of Research on Venture Capital. Cheltenham, UK: Edward Elgar.

Scott, W. R. 1995. Institutions and Organizations: Ideas and Interests. Thousand Oaks, CA: Sage.

Szerb, L., Rappai, G., Makra, Z., \& Terjesen, S. 2007. Informal investment in transition economies: Individual Characteristics and Clusters. Small Business Economics, 28: 257-271.

Shane, S. 2009. Fool's Gold: The Truth Behind Angel Investing in America. New York: Oxford University Press.

Shapiro, S. P. 1987. The social control of impersonal trust. American Journal of Sociology, 93: 623-658.

Shepherd, D. A., Zacharakis, A., \& Baron, R. A., 2003. VCs' decision processes: Evidence suggesting more experience may not always be better. Journal of Business Venturing, 18: 381-401.

Shinkle, G. A., \& Kriauciunas, A. P. 2012. The impact of current and founding institutions on strength of competitive aspirations in transition economies. Strategic Management Journal, 33: 448-458.

Short, D. M., \& Riding, A. L. 1989. Informal investors in the Ottawa-Carleton region: experiences and expectations. Entrepreneurship \& Regional Development, 1(1): 99-112.

Slovic, P., \& Lichtenstein, S. 1971. Comparison of Bayesian and regression approaches to the study of information processing in judgment. Organizational Behavior and Human Performance, 6: 649-744.

Sudek R., 2006. Angel investment criteria. Journal of Small Business Strategy, 17: 89-103.

Tashiro, Y. 1999. Business angels in Japan. Venture Capital, 1: 259-273.

Van Osnabrugge, M., 2000. A comparison of business angel and venture capitalist investment procedures: An agency theory-based analysis. Venture Capital, 2: 91-109.

Webb, J. W., Tihanyi, L., Ireland, R. D., \& Sirmon, D.G. 2009. You say illegal, I say legitimate: Entrepreneurship in the informal economy. Academy of Management Review, 34: 492-510.

Weber, E. U., \& Hsee, C. K. 1998. Cross-cultural differences in risk perception but cross-cultural similarities in attitudes towards risk. Management Science, 44: 1205-1218.

Wetzel, W. E. J. 1981. Informal risk capital in New England. In K. H. Vesper (Ed.), Frontiers of Entrepreneurship Research, 217-245. Wellesley, MA: Babson College.

Wetzel, W. E. J. 1983. Angels and informal risk capital. Sloan Management Review, 24(4): 23-34.

Williamson, O. E., 1979. Transaction-cost economics: The governance of contractual relations. Journal of Law and Economics, 22: 233-261.

Wiltbank, R., Read, S., Dew, N., \& Sarasvathy, S. D. 2009. Prediction and control under uncertainty: Outcomes in angel investing. Journal of Business Venturing, 24: 116-133.

Xin, K. R., \& Pearce, J. L. 1996. Guanxi: connections as substitutes for formal institutional support. Academy of Management Journal, 39: 1641-1658.

York, Kenneth. M. 1989. Defining sexual harassment in workplaces: A policy-capturing approach. Academy of Management Journal, 32(4): 830-850.

Zacharakis, A. L., McMullen, J. S., \& Shepherd, D. A., 2007. Venture capitalists' decision policies across three countries: An institutional theory perspective. Journal of International Business Studies, 38: 691-708.

Zhou, K. Z., \& Poppo, L., 2010. Exchange hazards, relational reliability, and contracts in China: The contingent role of legal enforceability. Journal of International Business Studies, 41: 861-881. 
Figure 1 Angel Investor Selection Criteria under an Institutional Comparative Perspective

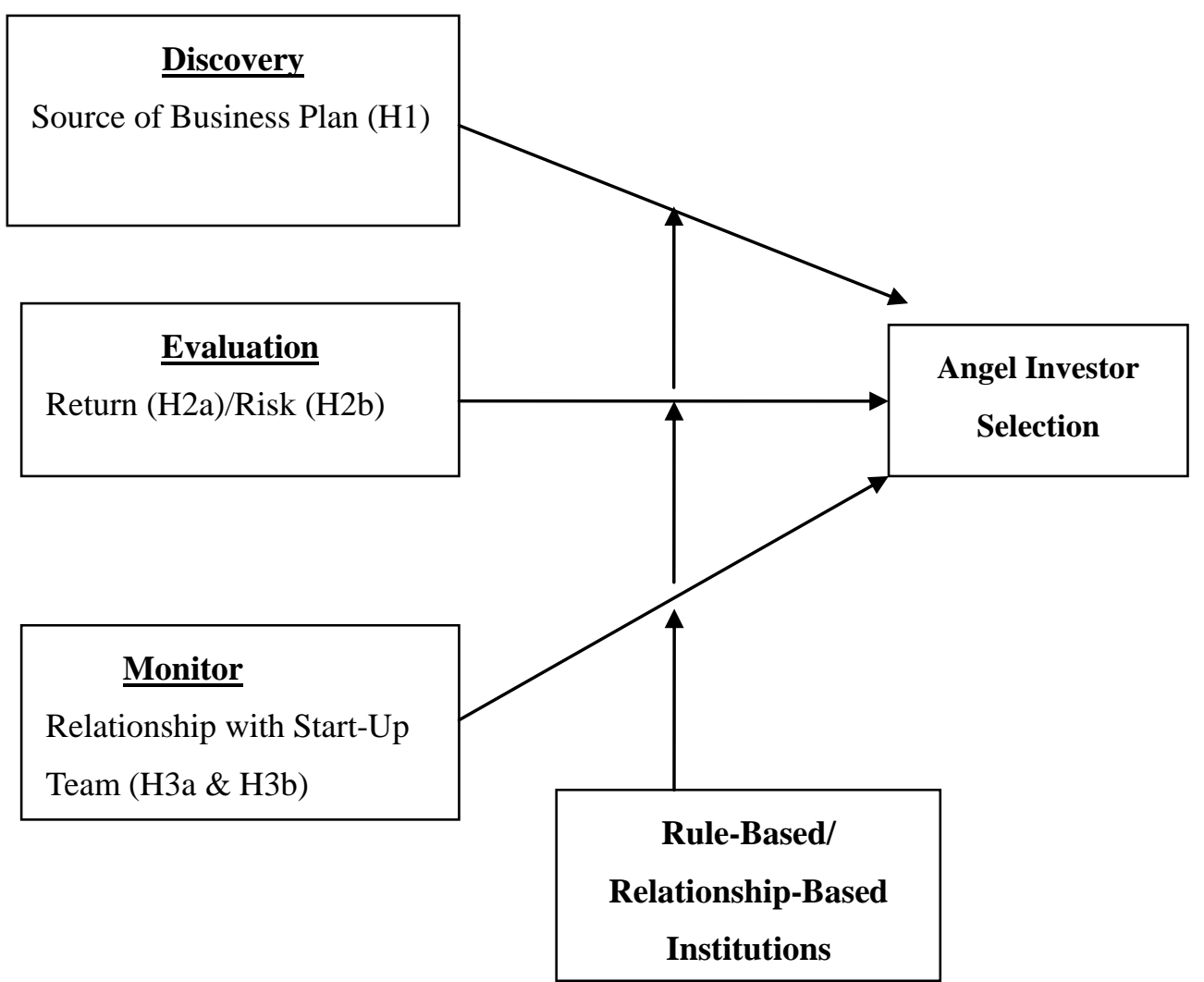




\begin{tabular}{|c|c|c|c|}
\hline & Institution & Relationship-Based Institution & Rule-Based Institution \\
\hline \multirow[t]{3}{*}{ 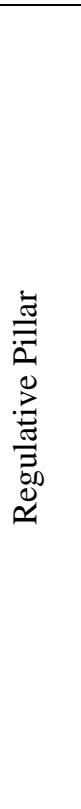 } & Characteristics & $\begin{array}{l}\text { Lack of a good legal system with enough property rights and investor } \\
\text { protection. } \\
\text { Personalized network-based transactions. } \\
\text { Enforcing contracts: out-of-court settlement, informal process, relying on } \\
\text { personal trust, informal agreements, and social tie pressure from trading } \\
\text { partner or community. } \\
\text { Capital market: immature and limited access. } \\
\text { Bankruptcy: a lengthy and inefficient, time-consuming process, firm } \\
\text { operations may or may not cease depending on negotiations, difficult for } \\
\text { entrepreneur to exit from debt claims. } \\
\text { Competition: limited access. }\end{array}$ & $\begin{array}{l}\text { A well-codified legal infrastructure such as commercial law, corporate } \\
\text { law, and contract law with sophisticated property right and investor } \\
\text { protections. } \\
\text { Impersonal arm's length transactions. } \\
\text { Enforcing contracts: formal process, relying on effective third-parties } \\
\text { such as courts and lawyers. } \\
\text { Capital market: mature, large force in firm valuation, financing, and } \\
\text { investment exit. } \\
\text { Bankruptcy: bankrupt entrepreneurs exit the firm and creditors claim } \\
\text { firm assets through court intervention. Firm operations cease (Lee et al., } \\
\text { 2007). } \\
\text { Competition: open access (North, Wallis, \&Weingast, 2009), } \\
\text { encouraging new entries and stimulating surviving firms to become } \\
\text { more efficient. }\end{array}$ \\
\hline & $\begin{array}{l}\text { Entrepreneur's } \\
\text { Response }\end{array}$ & $\begin{array}{l}\text { Build loosely structured entrepreneurial networks to compensate for lack } \\
\text { of formal institutional protection (Xin \& Pearce, 1996). } \\
\text { Access critical resources with informal collaboration under informal } \\
\text { institutions (Webb et al., 2009). }\end{array}$ & $\begin{array}{l}\text { Interact with strangers to start and develop businesses. } \\
\text { - Access rich resources with formal institution's support. }\end{array}$ \\
\hline & $\begin{array}{l}\text { Angel Investor's } \\
\text { responses }\end{array}$ & $\begin{array}{l}\text { Rely on strong ties: provide trust and predictability but consume time and } \\
\text { effect to build (Peng \& Zhou, 2005). }\end{array}$ & $\begin{array}{l}\text { - Rely on weak ties: more heterogeneous information and investment } \\
\text { opportunities (Peng \& Zhou, 2005). }\end{array}$ \\
\hline \multirow{3}{*}{ 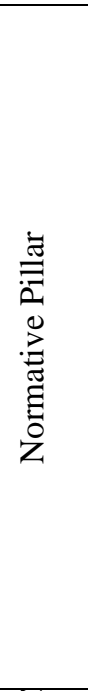 } & Characteristics & $\begin{array}{l}\text { Rules are opaque and ambiguous. } \\
\text { - } \quad \text { Public-private boundaries is blurred (Peng, 2001). } \\
\text { - Pervasive adoption of family business groups and crony capitalism in } \\
\text { Asia (Carney, Gedajlovic, \&Yang, 2009). } \\
\text { Concentrating economic power under powerful families in Latin America } \\
\text { (Bruton et al., 2009). }\end{array}$ & $\begin{array}{ll} & \text { Rules are stable and transparent. } \\
- & \text { Government and business have clear lines. } \\
\text { - Trust strangers and outsiders. }\end{array}$ \\
\hline & $\begin{array}{l}\text { Entrepreneur's } \\
\text { Responses }\end{array}$ & $\begin{array}{l}\text { Cultivate two sets of networks: 1/ suppliers, buyers, and alliances; } \\
\text { 2/rent-seeking government officials due to harassment from the } \\
\text { government (Peng, 2001). } \\
\text { Discover, evaluate and exploit opportunity through strong ties (Ma et al., } \\
\text { 2011). } \\
\text { Relationships with ties located in distant cities are harder to manage than } \\
\text { local ties (McMillan \& Woodruff, 2002). }\end{array}$ & $\begin{array}{l}\text { Explore and create new market with new technology. } \\
\text { Discover, evaluate. and exploit opportunity through weak ties (Ma et al., } \\
\text { 2011). }\end{array}$ \\
\hline & $\begin{array}{l}\text { Angel Investor's } \\
\text { Responses }\end{array}$ & $\begin{array}{l}\text { - Cultivate strong ties which have good relationship to exploit investment } \\
\text { opportunities such as linking to powerful families within the region } \\
\text { (Bruton et al., 2009; Peng \& Zhou, 2005). }\end{array}$ & $\begin{array}{l}\text { Establishing diversified weak ties to explore investment opportunities. } \\
\text { - Heavily rely on references to entrepreneur's personality. }\end{array}$ \\
\hline 00 & Characteristics & - Broadly held personal beliefs regarding responsibility. & - $\quad$ Beliefs and values centered on market competition. \\
\hline
\end{tabular}


Cushion effect: mutual help and support among in-group members.

\section{Entrepreneur's}

Responses

- Partner with strong ties to avoid adverse selection. Could be overembedded in family and social ties (Ahlstrom et al., 2007). Lost "face" if violating the investor's rights.

- Bribing is justifiable (Djankov, Qian, Roland, \& Zhuravskaya, 2006).

- A group's collective identity enhance the opportunity recognition (Webb et al., 2009).

- Strong attitude that the firm is theirs, and the investor should not interfere (Bruton et al., 2009).

Angel Investor's $\quad$ - Investment criteria emphasize human capital factors (leadership, market Responses familiarity, and start-up experiences) (Zacharakis et al., 2007).

- Focus competition based on market-based capabilities.

- Keeps fiduciary duty to investor. growth, propriety technology, number of competitor, and competitor growth, propriety technology, number
strength) (Zacharakis et al., 2007). 
Table 2a China and Denmark Comparison from Other Data Sources

\begin{tabular}{|c|c|c|c|}
\hline Items & China/Chinese & Denmark/Danish & Source \\
\hline Area & $9,596,961 \mathrm{sq} \mathrm{km}$ & $43,094 \mathrm{sq} \mathrm{km}$ & CIA Database \\
\hline Ethnic Groups & Han $91.5 \%$ (other 55 minor) & 7 & CIA Database \\
\hline Population 2011 & $1,336,718,015$ (rank 1) & 5,529,888 (rank 111) & CIA Database \\
\hline Administrative Divisions & $\begin{array}{l}32 \text { Provinces/Autonomous } \\
\text { Regions/Municipalities }\end{array}$ & 5 regions & CIA Database \\
\hline $\begin{array}{l}\text { GDP (purchasing power parity) } \\
2011\end{array}$ & $\$ 11300$ Billion (rank 3) & $\begin{array}{l}\$ 208.8 \text { billion (rank } \\
54)\end{array}$ & CIA Database \\
\hline GDP Growth 2011 & $9.5 \%($ rank 6$)$ & $1.5 \%(\operatorname{rank} 177)$ & CIA Database \\
\hline $\begin{array}{l}\text { Commercial Bank Prime Lending } \\
\text { Rate }\end{array}$ & $6.6 \%($ rank 157$)$ & $4.5 \%($ rank 170) & CIA Database \\
\hline Economic Freedom Rank 2012 & 138 & 11 & Heritage Foundation \\
\hline Corruption Perceptions Index 2011 & 3.6 (No. 76) & 9.4 (No.2) & $\begin{array}{l}\text { Transparency } \\
\text { International }\end{array}$ \\
\hline $\begin{array}{l}\text { Early-Stage Entrepreneurship } \\
\text { Activities (TEA: percentage of } \\
\text { adults) }\end{array}$ & $24.0 \%$ & $4.6 \%$ & GEM 2011 \\
\hline Angel Investor Prevalence Rate & $9.41 \%$ & $2.05 \%$ & GEM 2007 \\
\hline Discontinuation of Business & $5.3 \%$ & $2.3 \%$ & GEM 2011 \\
\hline Fear of Failure & $35.6 \%$ & 40.5 & GEM 2011 \\
\hline Corporate Governance & -0.52 & 1.84 & $\begin{array}{l}\text { World Bank } \\
\text { Governance Index }\end{array}$ \\
\hline Social Trust & $55.3 \%$ & $58.3 \%$ & World Value Survey \\
\hline Divorce/Marriage Ratio & $22.03 \%$ & $42.25 \%$ & World Bank \\
\hline Public Social Security Expenditure & $5.97 \%$ & $27.1 \%$ & La Porta, et al., 1997 \\
\hline $\begin{array}{l}\text { Highest Rates of } \\
\text { Personal Income Tax } 2010\end{array}$ & $45 \%$ & $55.4 \%$ & KPMG \\
\hline Materialist & $23.5 \%$ & $3.6 \%$ & $\begin{array}{l}\text { World Value Survey/ } \\
\text { Inglehart's Indicators }\end{array}$ \\
\hline Postmaterialist & $0.3 \%$ & $7.2 \%$ & $\begin{array}{l}\text { World Value Survey/ } \\
\text { Inglehart's Indicators }\end{array}$ \\
\hline \multicolumn{4}{|l|}{ Culture } \\
\hline Performance Orientation (practice) & 4.45 & 4.22 & GLOBE \\
\hline Performance Orientation (value) & 5.67 & 5.61 & GLOBE \\
\hline Uncertainty Avoidance (practice) & 4.94 & 5.22 & GLOBE \\
\hline Uncertainty Avoidance (value) & 5.28 & 3.82 & GLOBE \\
\hline Humane Orientation (practice) & 4.36 & 4.44 & GLOBE \\
\hline Humane Orientation (value) & 5.32 & 5.45 & GLOBE \\
\hline $\begin{array}{l}\text { Institutional Collectivism } \\
\text { (practice) }\end{array}$ & 4.56 & 4.19 & GLOBE \\
\hline Institutional Collectivism (value) & 4.77 & 4.8 & GLOBE \\
\hline Ingroup Collectivism (practice) & 5.8 & 3.53 & GLOBE \\
\hline Ingroup Collectivism (value) & 5.09 & 5.5 & GLOBE \\
\hline Assertiveness (practice) & 3.76 & 3.8 & GLOBE \\
\hline Assertiveness (value) & 5.44 & 3.39 & GLOBE \\
\hline Power Distance (practice) & 5.04 & 3.89 & GLOBE \\
\hline Power Distance (value) & 3.1 & 2.76 & GLOBE \\
\hline Future Orientation (practice) & 3.75 & 4.44 & GLOBE \\
\hline Future Orientation (value) & 4.73 & 4.33 & GLOBE \\
\hline
\end{tabular}


Table 2b Comparison of China and Denmark: World Bank Doing Business Report 2011

\begin{tabular}{|c|c|c|c|c|c|}
\hline Rankings & China & Denmark & Indicator Detail & China & Denmark \\
\hline $\begin{array}{c}\text { Ease of Doing } \\
\text { Business }\end{array}$ & 79 & 6 & & & \\
\hline \multirow[t]{4}{*}{ Acquiring Credit } & \multirow[t]{4}{*}{65} & \multirow[t]{4}{*}{15} & Strength of Legal Rights Index (0-10) & 6 & 9 \\
\hline & & & Depth of Credit Information Index (0-6) & 4 & 4 \\
\hline & & & Public Registry Coverage ( $\%$ of adults) & 63.9 & 0.0 \\
\hline & & & Private Bureau Coverage ( $\%$ of adults) & 0.0 & 5.4 \\
\hline \multirow[t]{4}{*}{ Protecting Investors } & \multirow[t]{4}{*}{93} & \multirow[t]{4}{*}{28} & Extent of Disclosure Index (0-10) & 10 & 7 \\
\hline & & & Extent of Director Liability Index (0-10) & 1 & 5 \\
\hline & & & Ease of Shareholder Suits Index (0-10) & 4 & 7 \\
\hline & & & $\begin{array}{l}\text { Strength of Investor Protection Index } \\
(0-10)\end{array}$ & 5.0 & 6.3 \\
\hline \multirow[t]{6}{*}{ Trading Across Borders } & \multirow[t]{6}{*}{50} & \multirow[t]{6}{*}{5} & Documents to Export (number) & 7 & 4 \\
\hline & & & Time to Export (days) & 21 & 5 \\
\hline & & & Cost to Export (US\$ per container) & 500 & 744 \\
\hline & & & Documents to Import (number) & 5 & 3 \\
\hline & & & Time to import (days) & 24 & 5 \\
\hline & & & Cost to import (US\$ per container) & 545 & 744 \\
\hline \multirow[t]{3}{*}{ Closing a Business } & \multirow[t]{3}{*}{68} & \multirow[t]{3}{*}{5} & Recovery Rate (cents on the dollar) & 36.4 & 89.4 \\
\hline & & & Time (years) & 1.7 & 1.1 \\
\hline & & & Cost $(\%$ of estate $)$ & 22 & 4 \\
\hline
\end{tabular}


Table 3 Selection Criteria of Angel Investor

\begin{tabular}{|l|l|}
\hline Variables & Description \\
\hline Main Variables & \\
\hline Source of Business Plan (H1) & $\begin{array}{l}\text { 1. Cold call by the startup team; 2.personal friends; 3. } \\
\text { professional market intermediary. }\end{array}$ \\
\hline Investment Return (H2a) & Scale ranging from 1(low return) to 3 (high return). \\
\hline Risk of Failure (H2b) & $\begin{array}{l}\text { Scale ranging from 1 (possibly huge loss) to 3 (possibly } \\
\text { little loss). }\end{array}$ \\
\hline $\begin{array}{l}\text { Relationship between Investor and Members } \\
\text { of Start-up Team (H3a\&b) }\end{array}$ & 1. Strangers; 2.friends; 3.family. \\
\hline Control Variables & $\begin{array}{l}\text { Scale ranging from 1 (low compatibility) to 3 (high } \\
\text { compatibility). }\end{array}$ \\
\hline $\begin{array}{l}\text { Compatibility with Investor Expertise and } \\
\text { Interest }\end{array}$ & Scale ranging from 1 (no good) to 3 (very good). \\
\hline Start-up Team Capabilities and Track Record & Scale ranging from 1 (not at all) to 3 (likely). \\
\hline Opportunity for Involvement in New Venture & 1. No exit plan; 2.exit plan exists. \\
\hline Exit Plan & \multicolumn{2}{|l}{} \\
\hline
\end{tabular}


Table 4 Descriptive Statistics and Correlations for Level-1 and Level-2 Variables

\begin{tabular}{|c|c|c|c|c|c|c|c|c|c|c|c|c|}
\hline & Mean & S.D. & 1 & 2 & 3 & 4 & 5 & 6 & 7 & 8 & 9 & 10 \\
\hline 1.Relation-Friend & 0.50 & 0.500 & & & & & & & & & & \\
\hline 2.Relation-Family & 0.26 & 0.441 & -0.592 & & & & & & & & & \\
\hline 3.Return & 2.00 & 0.706 & -0.046 & 0.037 & & & & & & & & \\
\hline 4.Risk & 2.03 & 0.704 & 0.010 & -0.023 & -0.029 & & & & & & & \\
\hline 5.Source- Professional & 0.50 & 0.500 & 0.017 & -0.020 & -0.043 & 0.000 & & & & & & \\
\hline 6.Source- Friend & 0.24 & 0.426 & -0.018 & 0.037 & 0.038 & -0.067 & -0.559 & & & & & \\
\hline 7.Compatibility & 2.03 & 0.688 & 0.004 & 0.029 & 0.016 & 0.007 & 0.035 & 0.048 & & & & \\
\hline 8.Team Capability & 1.95 & 0.699 & -0.032 & 0.022 & -0.005 & 0.007 & -0.047 & -0.019 & 0.012 & & & \\
\hline 9.Involvement & 2.05 & 0.713 & -0.011 & -0.001 & 0.003 & 0.004 & -0.023 & -0.019 & 0.035 & -0.010 & & \\
\hline 10.Exit & 0.66 & 0.633 & -0.020 & 0.073 & -0.049 & -0.035 & 0.040 & 0.004 & 0.009 & 0.013 & 0.034 & \\
\hline 11.Investment tendency & 2.86 & 1.096 & 0.035 & 0.070 & 0.241 & 0.344 & 0.074 & 0.014 & 0.208 & 0.261 & 0.115 & 0.099 \\
\hline Level-2 Variables ${ }^{\text {b }}$ & Mean & S.D. & 1 & 2 & 3 & 4 & 5 & 6 & & & & \\
\hline 1.Age & 2.32 & 0.485 & & & & & & & & & & \\
\hline 2.Gender & 1.06 & 0.612 & -0.261 & & & & & & & & & \\
\hline 3.Income & 2.03 & 1.096 & 0.489 & -0.269 & & & & & & & & \\
\hline 4.Education & 4.51 & 0.565 & -0.071 & -0.111 & 0.122 & & & & & & & \\
\hline 5.Informal Investment & 0.04 & 0.201 & -0.137 & -0.020 & -0.006 & 0.108 & & & & & & \\
\hline 6.Finance Investment & 0.67 & 0.473 & 0.281 & -0.367 & 0.431 & 0.387 & 0.147 & & & & & \\
\hline 7.Start-up Experience & 0.27 & 0.618 & 0.359 & -0.290 & 0.402 & -0.005 & 0.387 & 0.152 & & & & \\
\hline
\end{tabular}

${ }^{\mathrm{a}} \mathrm{n} 1=904$;

${ }^{\mathrm{b}} \mathrm{n} 2=113$. 
Table 5 China and Denmark Comparison-HLM Regression

\begin{tabular}{|c|c|c|c|c|c|c|}
\hline & \multicolumn{3}{|c|}{ Full Sample (China and Denmark) } & \multirow{2}{*}{$\frac{\text { China }}{\text { Model } 4}$} & \multicolumn{2}{|l|}{ Denmark } \\
\hline & Model 1 & Model 2 & Model 3 & & Model5 & $\begin{array}{c}\text { z (Difference } \\
\text { Tests) }\end{array}$ \\
\hline \multicolumn{7}{|l|}{ Level -1 } \\
\hline \multicolumn{7}{|l|}{ Independent Variable } \\
\hline Source- Friend & $0.308(0.091)^{* * *}$ & $0.308(0.091)^{* * *}$ & $0.357(0.086)^{* * *}$ & $0.408(0.113)^{* * *}$ & $0.216(0.119)+$ & 1.1 \\
\hline Return & $0.590(0.041)^{* * *}$ & $0.591(0.041)^{* * *}$ & $0.592(0.039)^{* * *}$ & $0.601(0.056)^{* * *}$ & $0.582(0.058) * * *$ & 0.15 \\
\hline Risk & $0.411(0.049)^{* * *}$ & $0.411(0.049)^{* * *}$ & $0.414(0.046)^{* * *}$ & $0.291(0.063)^{* * *}$ & $0.547(0.059)^{* * *}$ & $-1.62 *$ \\
\hline Relation-Friend & $0.263(0.077)^{* * *}$ & $0.264(0.077)^{* * *}$ & $0.264(0.071)^{* * *}$ & $0.430(0.106)^{* * *}$ & $0.141(0.101)$ & $1.64 *$ \\
\hline Relation-Family & $0.304(0.085)^{* * *}$ & $0.304(0.086)^{* * *}$ & $0.271(0.083)^{* *}$ & $0.549(0.114)^{* * *}$ & $0.064(0.114)$ & $2.85 * *$ \\
\hline \multicolumn{7}{|l|}{ Control Variables } \\
\hline Source- Professional & $0.352(0.081)^{* * *}$ & $0.353(0.081)^{* * *}$ & $0.382(0.076)^{* * *}$ & $0.436(0.116)^{* * *}$ & $0.233(0.104)^{*}$ & \\
\hline Compatibility & $0.298(0.044)^{* * *}$ & $0.301(0.045)^{* * *}$ & $0.317(0.040)^{* * *}$ & $0.354(0.057)^{* * *}$ & $0.435(0.061)^{* * *}$ & \\
\hline Team Capability & $0.439(0.049)^{* * *}$ & $0.440(0.049)^{* * *}$ & $0.453(0.045)^{* * *}$ & $0.423(0.057)^{* * *}$ & $0.244(0.062)^{* * *}$ & \\
\hline Involvement & $0.165(0.037)^{* * *}$ & $0.162(0.037)^{* * *}$ & $0.165(0.037)^{* * *}$ & $0.124(0.055)^{*}$ & $0.195(0.058)^{* * *}$ & \\
\hline Exit & $0.269(0.065)^{* * *}$ & $0.281(0.068)^{* * *}$ & $0.287(0.062)^{* * *}$ & $0.272(0.078) * * *$ & $0.313(0.077)^{* * *}$ & \\
\hline \multicolumn{7}{|l|}{ Level-2 } \\
\hline \multicolumn{7}{|l|}{ Control Variables } \\
\hline Age & & $-0.056(0.123)$ & $-0.042(0.126)$ & $0.006(0.146)$ & $-0.445(0.280)$ & \\
\hline Gender & & $0.026(0.084)$ & $0.024(0.093)$ & $0.112(0.175)$ & $-0.041(0.127)$ & \\
\hline Income & & $0.013(0.044)$ & $0.026(0.059)$ & $-0.007(0.070)$ & $0.031(0.132)$ & \\
\hline Education & & $-0.089(0.075)$ & $-0.072(0.076)$ & $-0.029(0.112)$ & $-0.022(0.132)$ & \\
\hline Informal Investment & & $0.044(0.223)$ & $-0.032(0.208)$ & $-0.311(0.364)$ & $0.771(0.474)$ & \\
\hline Finance Investment & & $-0.043(0.114)$ & $-0.072(0.113)$ & $-0.076(0.236)$ & $-0.134(0.131)$ & \\
\hline Start-up Experience & & $0.132(0.138)$ & $0.098(0.122)$ & & & \\
\hline China & & & $0.037(0.188)$ & & & \\
\hline \multicolumn{7}{|l|}{ Interaction } \\
\hline China*Source-Friend (H1) & & & $0.275(0.176)$ & & & \\
\hline China* Return (H2a) & & & $0.024(0.076)$ & & & \\
\hline China* Risk (H2b) & & & $-0.234(0.092)^{*}$ & & & \\
\hline China*Relation-Friend (H3a) & & & $0.233(0.137)+$ & & & \\
\hline China*Relation-Family (H3b) & & & $0.368(0.166)^{*}$ & & & \\
\hline Intercept & $2.788(0.044)^{* * *}$ & $2.789(0.043)^{* * *}$ & $2.785(0.043)^{* * *}$ & $2.820(0.064)^{* * *}$ & $2.751(0.058)^{* * * *}$ & \\
\hline Sample & 904 & 904 & 904 & 480 & 424 & \\
\hline R-squared & $34.24 \%$ & $33.57 \%$ & $47.93 \%$ & $30.24 \%$ & $38.06 \%$ & \\
\hline
\end{tabular}

The number in parenthesis is the standard error. $+\mathrm{p}<0.10 ; * \mathrm{p}<0.05 ; * * \mathrm{p}<0.01 ; * * * \mathrm{p}<0.001$. 